Article

\title{
Green Synthesized Zinc Oxide (ZnO) Nanoparticles Induce Oxidative Stress and DNA Damage in Lathyrus sativus L. Root Bioassay System
}

\author{
Kamal K. Panda ${ }^{1}$, Dambaru Golari ${ }^{1}$, A. Venugopal ${ }^{1}$, V. Mohan M. Achary ${ }^{2}$, \\ Ganngam Phaomei ${ }^{3}$, Narasimham L. Parinandi ${ }^{4}$, Hrushi K. Sahu ${ }^{5,+}$ and Brahma B. Panda ${ }^{1, *}$ \\ 1 Molecular Biology and Genomics Laboratory, Department of Botany, Berhampur University, \\ Berhampur 760007, Odisha, India; kamalpanda51@gmail.com (K.K.P.); dambarugolari@gmail.com (D.G.); \\ venu86job@gmail.com (A.V.) \\ 2 Plant Molecular Biology Group, International Centre for Genetic Engineering and Biotechnology, \\ New Delhi 110067, India; achary.mohan1@gmail.com \\ 3 Material Chemistry Laboratory, Department of Chemistry, Berhampur University, Berhampur 760007, \\ Odisha, India; g.phaomei@gmail.com \\ 4 Division of Pulmonary, Allergy, Critical Care, and Sleep Medicine, Department of Medicine, Davis Heart \\ and Lung Research Institute, Ohio State University College of Medicine, Columbus, OH 43210, USA; \\ narasimham.parinandi@osumc.edu \\ 5 Condensed Matter Physics Division, Indira Gandhi Centre for Atomic Research, Kalpakum, \\ Tamil Nadu 603102, India; sahuhk@gmail.com \\ * Correspondence: panda.brahma@gmail.com \\ † Present address: C/92 Vidya Nilaya, Shanti Nagar, Goilundi, Berhampur 760004, India.
}

Academic Editor: Vytas Reipa

Received: 15 March 2017; Accepted: 15 May 2017; Published: 18 May 2017

\begin{abstract}
Zinc oxide nanoparticles (ZnONP-GS) were synthesised from the precursor zinc acetate $\left(\mathrm{Zn}\left(\mathrm{CH}_{3} \mathrm{COO}\right)_{2}\right)$ through the green route using the milky latex from milk weed (Calotropis gigantea $\mathrm{L}$. $\mathrm{R}$. Br) by alkaline precipitation. Formation of the ZnONP-GS was monitored by UV-visible spectroscopy followed by characterization and confirmation by energy-dispersive X-ray spectroscopy (EDX), transmission electron microscopy (TEM), and X-ray diffraction (XRD). Both the ZnONP-GS and the commercially available $\mathrm{ZnONP}-\mathrm{S}$ (Sigma-Aldrich) and cationic $\mathrm{Zn}^{2+}$ from $\mathrm{Zn}\left(\mathrm{CH}_{3} \mathrm{COO}\right)_{2}$ were tested in a dose range of $0-100 \mathrm{mg} \cdot \mathrm{L}^{-1}$ for their potency (i) to induce oxidative stress as measured by the generation reactive oxygen species (ROS: $\mathrm{O}_{2}{ }^{\bullet-}, \mathrm{H}_{2} \mathrm{O}_{2}$ and ${ }^{\bullet} \mathrm{OH}$ ), cell death, and lipid peroxidation; (ii) to modulate the activities of antioxidant enzymes: catalase (CAT), superoxide dismutase (SOD), guaiacol peroxidase (GPX), and ascorbate peroxidase (APX); and (iii) to cause DNA damage as determined by Comet assay in Lathyrus sativus L. root bioassay system. Antioxidants such as Tiron and dimethylthiourea significantly attenuated the ZnONP-induced oxidative and DNA damage, suggesting the involvement of ROS therein. Our study demonstrated that both ZnONP-GS and ZnONP-S induced oxidative stress and DNA damage to a similar extent but were significantly less potent than $\mathrm{Zn}^{2+}$ alone.
\end{abstract}

Keywords: zinc oxide nanoparticles; green synthesis; Calotropis gigantea; plant bioassay; Lathyrus sativus root; oxidative stress; comet assay; reactive oxygen species

\section{Introduction}

At present, metal oxide nanoparticles (NPs), owing to their optical, electrical, and magnetic properties, are sought after materials for applications in the fields of energy storage, sensors, data storage, optics, transmission, cosmetics, biotechnology, and medicine. To meet the growing 
demand for NPs, they are manufactured in large scale for industrial and household uses. The increasing use of NPs leads to their release into the environment and serious risk of ecotoxicity [1-3]. Hence, metal oxide NPs emerge as a novel class of environmental xenobiotics, the toxicity/hazard of which needs to be assessed on a priority basis. Furthermore, plants, as lifeforms of the first trophic level, are at the forefront of encountering environmental NPs. Therefore, there is a pressing need to obtain vital knowledge on the adverse effects of NPs on plants towards obtaining the crucial environmental impact assessment of NPs.

Among metal oxide NPs, zinc oxide nanoparticles (ZnONPs) with unique optical and electrical properties are suitable for many applications such as coatings for the solar cells, electronics, and chemical sensors. The ZnONP blocks the UV-radiation and therefore is used in transparent UV-protection films and as a UV-filter in sunscreens [4]. Due to its antimicrobial properties, ZnONP is included in the linings for canning meat, fish, corn, and peas [5]. Recent studies demonstrate that ZnONPs hold considerable promise for biomedical applications and therapeutic intervention [6]. The ZnONP-amended agricultural soils depending on the soil-properties cause phytotoxicity in wheat seedlings [7]. Therefore, the ecotoxicity of the ZnONPs in diverse organisms is of serious concern [8].

Many alternative physico-chemical [9-13] and biological or plant-mediated [14,15] synthesis routes have been used to prepare ZnONPs. The latter methods using microbes and plant extracts are preferred for the synthesis of NPs, which are considered eco-friendly. The relatively simple bottom-up approach using the plant extracts, also known as green synthesis (GS), minimizes or eliminates hazardous chemicals normally used in physico-chemical synthesis of NPs. Furthermore, GS is preferred for the synthesis of metallic NPs due to reasonable (low) cost, less or no toxicity, and other environmental advantages [16]. GS of the ZnONP utilizes the extracts of different plants, including Acalypha indica, Aloe vera, Calotropis gigantea, C. procera, Catharanthus roseus, Coriandrum sativum, and Ixora coccinia [17-21], as well as extracts of the algal seaweeds [22]. Among currently available methods of GS, the present study utilized the alkaline precipitation method to synthesize the $\mathrm{ZnONP}$ by reduction of the precursor, zinc acetate $\left(\mathrm{Zn}\left(\mathrm{CH}_{3} \mathrm{COO}\right)_{2}\right)$, using sodium hydroxide $(\mathrm{NaOH})$ along with the milky latex of $C$. gigantea. Furthermore, the potential of ZnONP synthesized by the green route (henceforth referred as ZnONP-GS) to induce oxidative stress and DNA damage was determined in comparison with that of the commercially available ZnONP-S (Sigma-Aldrich, St. Louis, MO, USA) and $\mathrm{Zn}^{2+}$ ion from $\mathrm{Zn}\left(\mathrm{CH}_{3} \mathrm{COO}\right)_{2}$. In order to investigate the role of reactive oxygen species (ROS) in the phytotoxicity of the ZnONPs, well-established antioxidants such as Tiron (1,2-dihydroxybenzene-3,5-disulfonate) and dimethylthiourea (DMTU), which scavenge $\mathrm{O}_{2}{ }^{\bullet-}$ and $\mathrm{H}_{2} \mathrm{O}_{2}$ respectively, were used in this study. Oxidative and DNA damage assays were carried out by employing the Lathyrus sativus L. root bioassay system [23].

\section{Materials and Methods}

\subsection{Synthesis of $\mathrm{ZnONP}$}

Fresh milky latex was collected by making an incision on the intact branches of a mature milk weed, Calotropis gigantea (L.) Dryand (Family: Apocyanacae, Subfamily: Asclepiadoideae). The freshly collected milky latex in different volumes $0.25,0.5$, or $1.0 \mathrm{~mL}$ was added to $100 \mathrm{~mL}$ aqueous solution of $0.01 \mathrm{M}$ zinc acetate, $\mathrm{Zn}\left(\mathrm{CH}_{3} \mathrm{COO}\right)_{2} 2 \mathrm{H}_{2} \mathrm{O}$ (Merck, Mumbai, India), with constant stirring at room temperature $\left(25 \pm 1{ }^{\circ} \mathrm{C}\right)$ for thorough mixing (1:100, by vol.). The initial $\mathrm{pH}$ recorded in the range of 7.6-7.8 was raised to $\mathrm{pH} 12$ by adding $2 \mathrm{M} \mathrm{NaOH}(\sim 2.4 \mathrm{~mL})$, which resulted in the appearance of white precipitation of ZnONP-GS within $10 \mathrm{~min}$. The ZnONP-GS was continuously mixed in the synthesis container for $2 \mathrm{~h}$ and then allowed to settle overnight at room temperature. The photoluminescence spectrum of the clear supernatant, owing to the surface plasmon resonance (SPR) of the clear supernatant obtained by centrifugation, was recorded in the wavelength range of 200 to $600 \mathrm{~nm}$ at a resolution setting of $0.1 \mathrm{~nm}$ on a UV-visible spectrophotometer (UV-3000+, LabIndia Instruments, Mumbai, India). The pellet of ZnONP-GS was collected by centrifugation at 12,000 rpm for 
$15 \mathrm{~min}$ followed by repeated washings with double distilled water and ethanol to remove the residual $\mathrm{Zn}^{2+}$ ion and other impurities. The absence of any free $\mathrm{Zn}^{2+}$ ion in the final wash was ascertained indirectly by measuring the conductivity with the aid of a conductivity meter (YSI Model 85, Yellow Springs, OH, USA). Finally, the ZnONP-GS were air dried for $48 \mathrm{~h}$ to a dry power. The absorbance of the supernatant from the ZnONP-GS suspension prepared using distilled water was also recorded for determination of SPR of the pure ZnONP-GS.

\subsection{Physical Characterisation of $\mathrm{ZnONP}$}

The green synthesized dry powder of the ZnONP-GS and the commercially available zinc oxide nanoparticles (ZnONP-S) (S: for Sigma-Aldrich, St. Louis, MO, USA) were subjected to X-ray Diffraction (XRD) for identification of the hexagonal wurtzite crystalline solid particles. The samples were smeared on a high index (911) Si plate, which was spun continuously to reduce the effect of any preferred orientation of the particles. The measurements were carried out on a Stoe diffractometer using $\mathrm{Cu} \mathrm{K} \alpha$ radiation operating at $45 \mathrm{kV}$ and $40 \mathrm{~mA}$. A coarse $\mathrm{ZnO}$ powder with a grain size of $\geq 25 \mu \mathrm{m}$ diameter ( $\mathrm{ZnO}$ Bulk) was used to find out the instrument broadening, and this was used for correcting the actual sample data.

For Transmission Electron Microscopy (TEM), samples of dry powder ( 1 mg) of the ZnONPs were mixed with ethanol in a $2 \mathrm{~mL}$ Eppendorf tube. The tubes were then placed in an ultrasonic bath for $10 \mathrm{~min}$ to disperse the NPs into a uniform suspension. A drop of the suspension was applied onto a 300 mesh copper grid coated with carbon film and dried for 10-30 min in ambient air, and the copper grid was subjected to a TEM examination (JEOL, JEM-2100F, USA operated at $200 \mathrm{kV}$ ). The sample was further analysed using Energy-Dispersive X-ray Spectroscopy (EDX, Bruker, Billerica, MA, USA) equipped with a liquid nitrogen free $\mathrm{XFlash}{ }^{\circledR}$ Detector at an energy resolution of $127 \mathrm{eV}$, accelerating voltage of $15 \mathrm{kV}$, beam current $20 \mathrm{nA}$, input count rate of 150,000 cps, acquisition time of $5 \mathrm{~min}$, and mapping resolution of $600 \times 450$ pixels. Also, the dry powder samples of milky latex and that of the latex-synthesizing mixture containing the ZnONP-GS were analyzed by Fourier Transform Infrared Spectroscopy (FTIR) using an IRPrestige-21 FTIR Spectrophotometer (Shimadzu, Nakagyo-ku, Kyoto, Japan) for the identification of functional groups, as described earlier [23].

\subsection{Plant Root Bioassay System}

The seeds of grass pea (Lathyrus sativus L., $2 n=14$ ) obtained from a local farm were used as the bioassay system. The seeds were surface sterilized in aqueous solutions of a $1 \%$ fungicide, Bavistin (BASF, Mumbai, India), thoroughly washed in sterile water, and pre-soaked for $48 \mathrm{~h}$ at $4{ }^{\circ} \mathrm{C}$ in distilled water to facilitate imbibition. Following complete imbibition, the seeds were wrapped in sterile moist cotton cloth and placed at $24 \pm 1{ }^{\circ} \mathrm{C}$ in the dark for germination. After $48 \mathrm{~h}$, the germinating seeds with $\sim 15 \mathrm{~mm}$ long roots were treated with the experimental solutions at different concentrations [23].

\subsection{Experimental Solutions and Treatment Protocol}

Experimental solutions of the ZnONPs were prepared by suspending known amounts (wt.) of the ZnONP-S and the ZnoNP-GS in distilled water under constant stirring for $1 \mathrm{~h}$ at different concentrations $\left(0,10,20,40,80,100 \mathrm{mg} \cdot \mathrm{L}^{-1}\right)$. Solutions of $\mathrm{Zn}\left(\mathrm{CH}_{3} \mathrm{COO}\right)_{2}\left(\mathrm{Zn}^{2+}\right)$ were likewise prepared in the above range of concentrations to serve as the positive control. The $\mathrm{pH}$ of the experimental solutions was adjusted to 7.0 prior to treatment. The germinating seeds were treated by immersing the sprouting roots in $150 \mathrm{~mL}$ of the experimental solutions at different concentrations in sterile plastic receptacles $(250 \mathrm{~mL}$ capacity) under continuous shaking on a rotary shaker for $15 \mathrm{~h}$. In other experiments, to demonstrate the involvement of ROS, germinating seeds were pre-treated (primed) with the $\mathrm{O}_{2}{ }^{\bullet-}$ scavenger, Tiron (Sigma-Aldrich, USA) and $\mathrm{H}_{2} \mathrm{O}$ scavenger, DMTU (Sigma-Aldrich, USA) at concentrations of 10 or $20 \mu \mathrm{M}$ for $5 \mathrm{~h}$ before the treatment with the $\mathrm{ZnONP}$ at $80 \mathrm{mg} \cdot \mathrm{L}^{-1}$ for the next $10 \mathrm{~h}$. For all the treatments, double distilled water was used as the negative control (0). The experiments were conducted at room temperature $\left(25 \pm 1^{\circ} \mathrm{C}\right)$ in the dark. At the end of the treatments, the germinating seeds with roots 
were thoroughly washed in running tap water and then processed for cytochemical visualization and spectrophotometric determination of the $\operatorname{ROS}\left(\mathrm{O}_{2}^{\bullet-}, \mathrm{H}_{2} \mathrm{O}_{2}\right.$ and $\left.\bullet \mathrm{OH}\right)$, cell death, lipid peroxidation, antioxidant enzymes activity, and DNA damage by Comet assay in the root tissue.

\subsection{Cytochemical Visualization and Spectrophotometric Determination of ROS, Cell Death, and Lipid Peroxidation}

The cellular generation of the $\operatorname{ROS}\left(\mathrm{O}_{2}{ }^{\bullet-}, \mathrm{H}_{2} \mathrm{O}_{2},{ }^{\bullet} \mathrm{OH}\right)$ and cell death were visualized by the cytochemical staining techniques and determined spectrophotometrically, as described earlier in detail [23]. The cytochemical detection of lipid peroxidation was performed by staining the root tissue with Schiff's reagent [24]. Furthermore, lipid peroxidation was determined spectrophotometrically as malondialdehyde (MDA) formed from the ROS-catalyzed membrane polyunsaturated fatty acid peroxidation by the thiobarbituric acid (TBA) reaction [25]. The amount of MDA-TBA complex (red pigment) was calculated from the extinction coefficient $\left(\varepsilon=155 \mathrm{mM}^{-1} \cdot \mathrm{cm}^{-1}\right)$ and expressed as $\mathrm{n}$ moles MDA. $\mathrm{g}^{-1}$ fresh weight (FW).

\subsection{Extraction of Soluble Protein and Enzyme Assays}

The root samples $(1 \mathrm{~g})$ from each treatment were homogenized in $2 \mathrm{~mL}$ of $50 \mathrm{mM}$ Tris- $\mathrm{HCl}$ buffer ( $\mathrm{pH} 7.2$ ) containing $0.1 \mathrm{mM}$ ethylenediaminetetraacetic acid (EDTA) and $1 \%(w / v)$ polyvinyl polypyrrolidone at $4{ }^{\circ} \mathrm{C}$. For the ascorbate peroxidase assay, the homogenization solution additionally contained $5 \mathrm{mM}$ ascorbate. The homogenates were centrifuged at $10,000 \times \mathrm{g}$ for $15 \mathrm{~min}$ at $4{ }^{\circ} \mathrm{C}$, and the resultant crude supernatant was collected and stored at $-20^{\circ} \mathrm{C}$ for the determination of protein and enzyme activities. The soluble protein content in the supernatant was determined by the Bradford method with bovine serum albumin as the standard [26].

The activities of antioxidant enzymes including catalase (CAT, EC. 1.11.1.6) [27], superoxide dismutase (SOD, EC. 1.15.1.1) [28], guaiacol peroxidase (GPX, EC. 1.11.1.7) [29], and ascorbate peroxidase (APX, EC. 1.11.1.11) [30], were determined spectrophotometrically as described earlier [31].

\subsection{Comet Assay}

For the alkaline comet assay, following the $15 \mathrm{~h}$ treatment, the germinating seeds with intact roots were removed from the treatment solutions followed by a thorough wash in distilled water. Then the $\sim 15 \mathrm{~mm}$ long roots were excised from the seeds and transferred to the glass slide on a 60-mm Petri dish on ice. Then the roots were immersed in $200 \mu \mathrm{L}$ of chilled Tris-HCl buffer $(0.4 \mathrm{M}, \mathrm{pH} 7.4)$ and sliced, and the nuclei were collected and processed for the Comet assay using an Olympus BX51 microscope with a fluorescence attachment (using the excitation filter of 515-560 nm and barrier filter of $590 \mathrm{~nm}$ ) equipped with a Cohu camera and Kinetic Komet ${ }^{\mathrm{TM}}$ Imaging Software 5.5 (Andor ${ }^{\mathrm{TM}}$ Technology, Belfast, UK, www.andor.com) according to the procedure described earlier [23]. Two slides prepared with the nuclear suspension obtained by slicing at least 15 primary roots (excised from 15 germinated seeds) were examined for each treatment. At least 50 randomly chosen comets were analyzed from each slide. The Comet assay was repeated three times so that a total of 300 comets from six slides prepared from 45 roots (45 germinated roots) were examined for each treatment. The comet images were visualized and captured at $100 \times$ magnification. Out of several parameters available in the software, the comets were analyzed based on the percentage (\%) DNA in tail as the measure of primary DNA damage [32]. The entire process of Comet assay was carried out in subdued or yellow light.

\subsection{Statistical Analysis}

All the experiments with the exception of the Comet assay, conducted in triplicate, were repeated once $(n=6)$. The Comet assay was repeated three times $(n=6)$. The pooled data were statistically analyzed for the analysis of variance (ANOVA), followed by Tukey's honestly significant difference (HSD) test [33] by employing Microsoft Excel 2003 or MATLAB software under the Windows ${ }^{\circledR}$ 7 platform. 


\section{Results}

\subsection{Synthesis and Characterization of ZnoNP-GS}

The raising of the $\mathrm{pH}$ of the latex- $\mathrm{Zn}\left(\mathrm{CH}_{3} \mathrm{COO}\right)_{2}$ mixture to 12 by the addition of $2 \mathrm{M} \mathrm{NaOH}$ facilitated the synthesis of ZnONP-GS that was noticeable by the white precipitation. The absorbance was monitored at the wavelength range of $200-600 \mathrm{~nm}$, which showed maximum absorbance $\left(\lambda_{\max }\right)$ at $281 \mathrm{~nm}$ (Figure 1). The $\lambda_{\max }$ observed for the pure ZnONP-GS was $306 \mathrm{~nm}$. The EDX profile showed a strong signal for $\mathrm{Zn}$ along with signals of $\mathrm{Cu}, \mathrm{C}$, and $\mathrm{O}$ (Figure 2). TEM images of the ZnONP-GS and ZnONP-S indicated their spherical to hexagonal shapes (Figure 3). The XRD profile of the ZnONP-GS also agreed well with that of the ZnONP-S used for comparison as well as with that of the standard ZnO bulk (Joint Committee on Power Diffraction Standards, JCPDF-36-1451) (Figure 4), which showed thirteen characteristic diffraction peaks of 100, 002, 101, 102, 110, 103, 200, 112, 201, $004,202,104$, and 203 , observed at $2 \theta$ angles; $31.77^{\circ}, 34.42^{\circ}, 36.25^{\circ}, 47.54^{\circ}, 56.6^{\circ}, 62.86^{\circ}, 66.38^{\circ}, 67.96^{\circ}$, $69.09^{\circ}, 72.56^{\circ}, 76.95^{\circ}, 81.37^{\circ}$, and $89.6^{\circ}$, respectively. The wurtzite crystalline structure of ZnONPs was thus established in conventionality with the JCPDS-36-1451 for ZnO bulk. The sizes of the ZnONP-GS and ZnONP-S were calculated by applying the Scherrer formula, taking into account the first four intense peaks, namely, the 100, 002, 101, and 102 diffraction peaks fitted to the Lorentzian peak shapes, and the diameters were estimated to be 25.1 and $48.6 \mathrm{~nm}$, respectively. The Fourier Transform Infrared (FITR) Spectroscopy profile of $C$. gigantea latex vis-à-vis the ZnONP-GS in latex (Figure 5) revealed the spectral differences marked by the absence of several peaks in the wavenumber range from $1600 \mathrm{~cm}^{-1}$ to $1400 \mathrm{~cm}^{-1}$ in ZnONP-GS (GS: green synthesis) found prominently in the spectrum of latex.

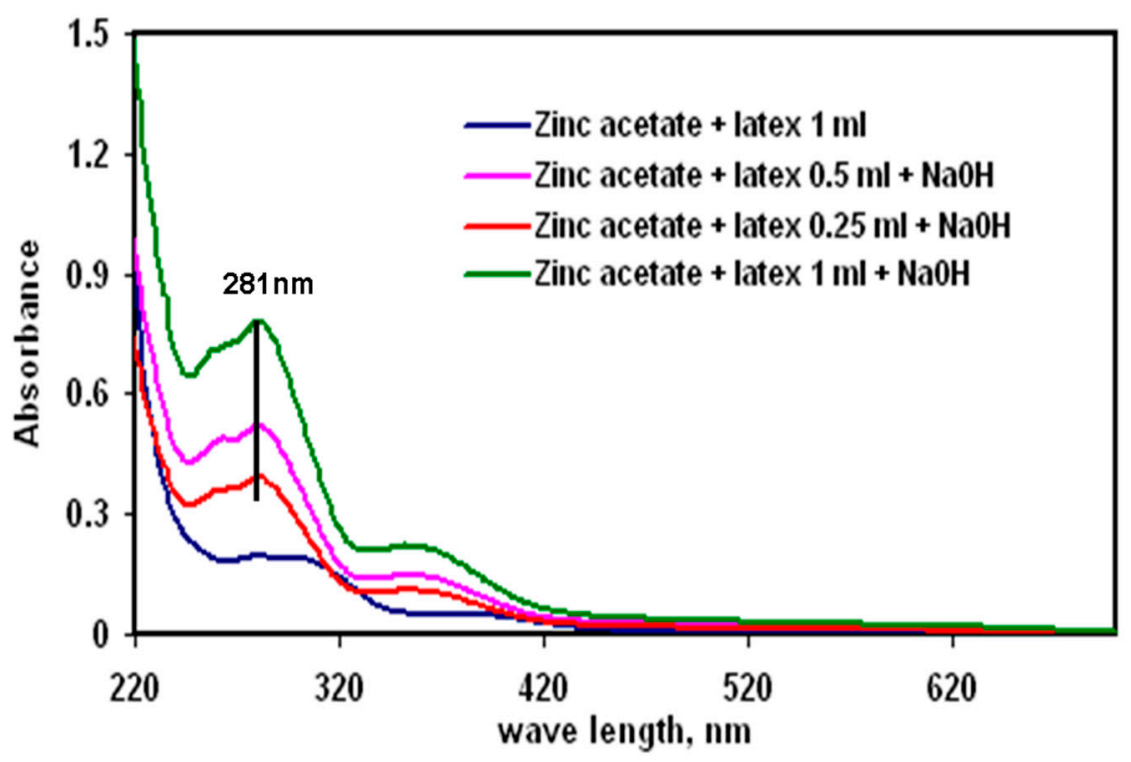

Figure 1. UV-Visible spectrum of a zinc oxide nanoparticle (ZnONP) synthesized by alkaline precipitation method using milky latex from $C$. gigantea at three different concentrations mixed with $100 \mathrm{~mL}$ of $0.1 \mathrm{M} \mathrm{Zn}\left(\mathrm{CH}_{3} \mathrm{COO}\right)_{2}$ solution to which $2 \mathrm{M} \mathrm{NaOH}$ solution was added drop wise under stirring to raise the $\mathrm{pH}$ to 12 . 


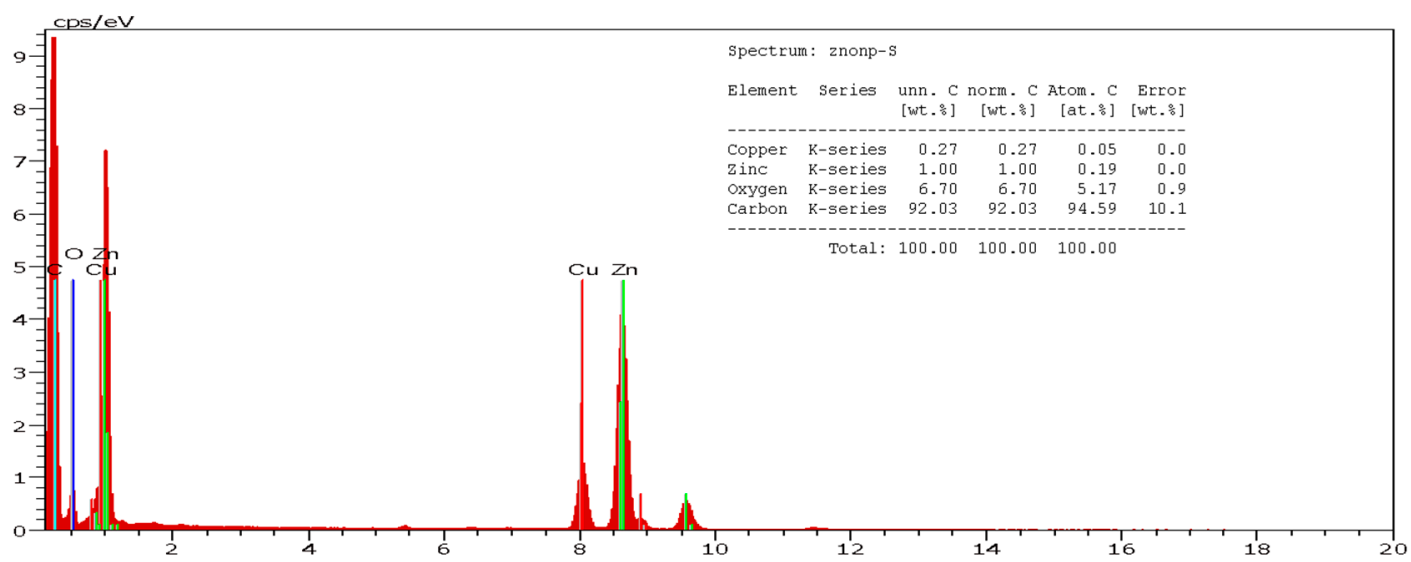

(A)

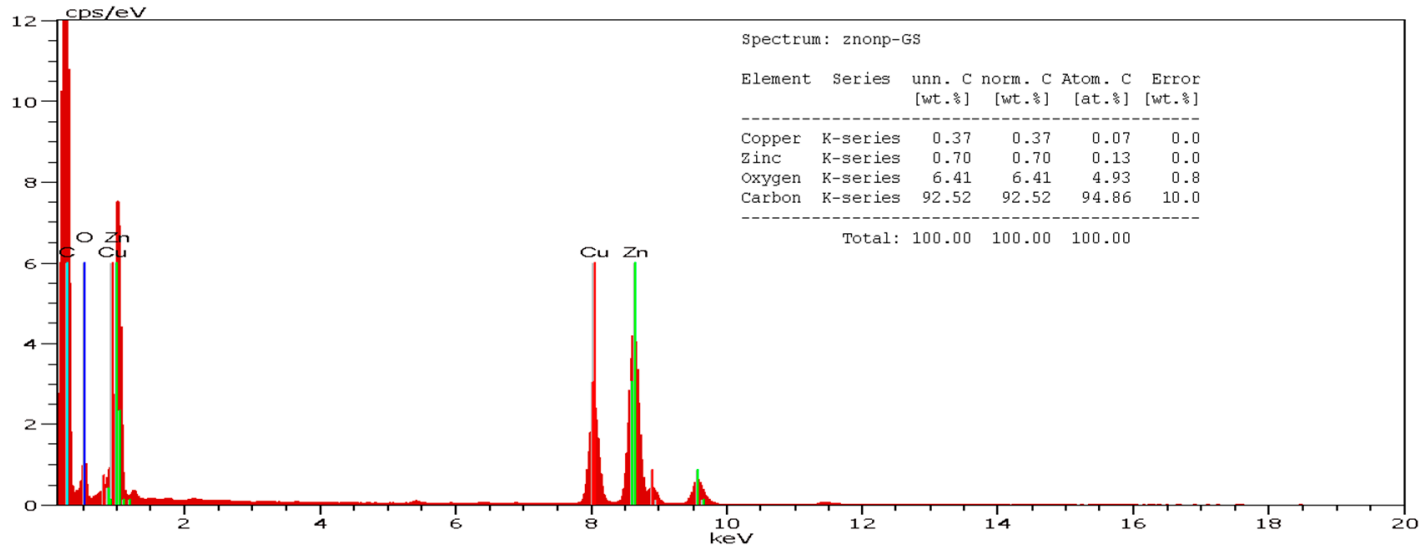

(B)

Figure 2. Energy-Dispersive X-ray Spectroscopy (EDX) spectrum of (A) ZnONP-S (procured from Sigma-Aldrich, USA) and (B) ZnONP-GS (green-synthesized in the current study) showing strong $\mathrm{Zn}$-signals against background signals of $\mathrm{C}, \mathrm{O}$, and $\mathrm{Cu}$.
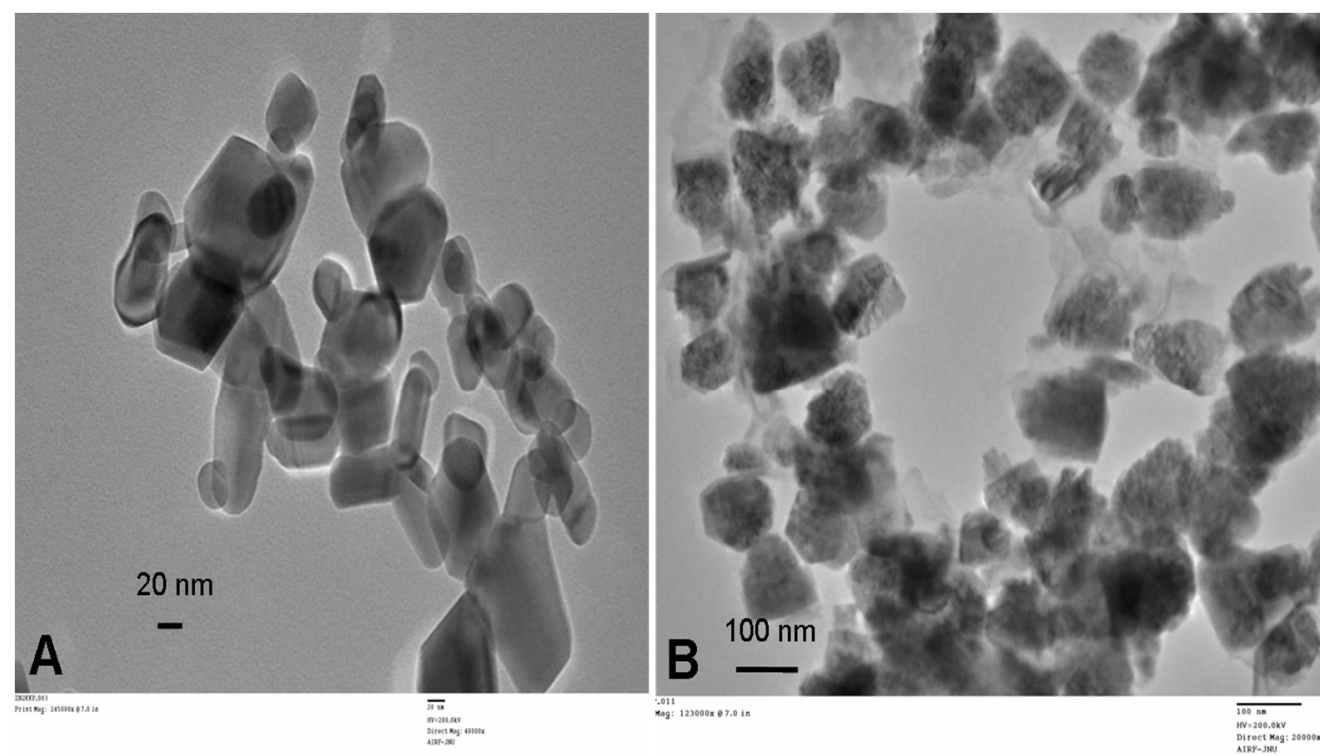

Figure 3. Transmission Electron Microscopy (TEM) images of (A) ZnONP-S and (B) ZnONP-GS. 

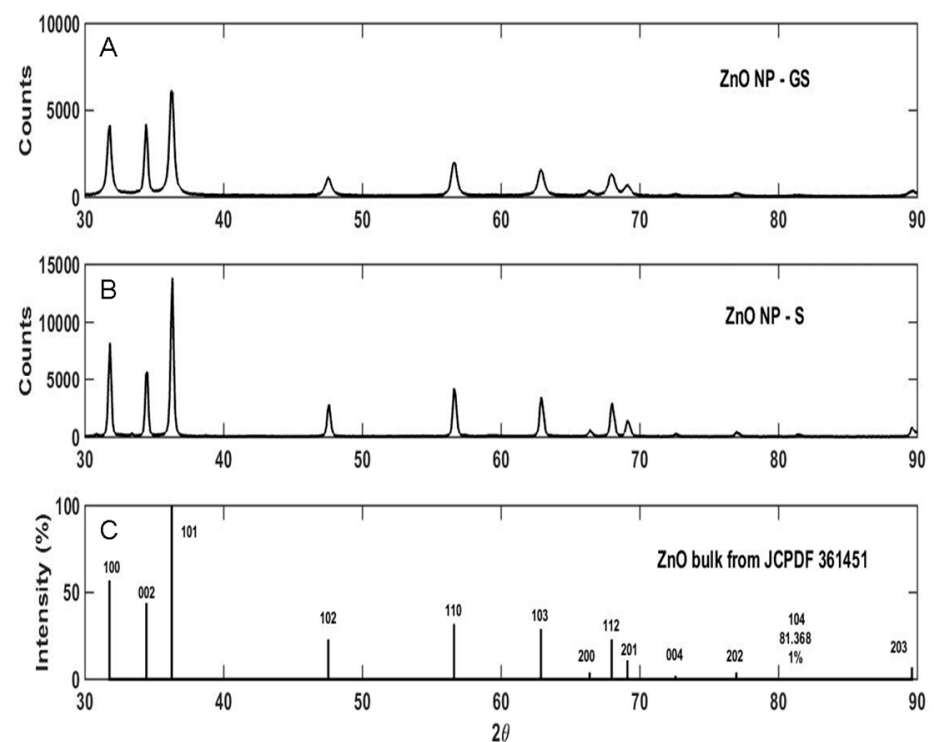

Figure 4. X-ray diffraction (XRD) pattern showing wurtzite crystalline structure of (A) ZnONP-GS and (B) ZnONP-S compared to (C) ZnO Bulk (JCPDS-36-1451).

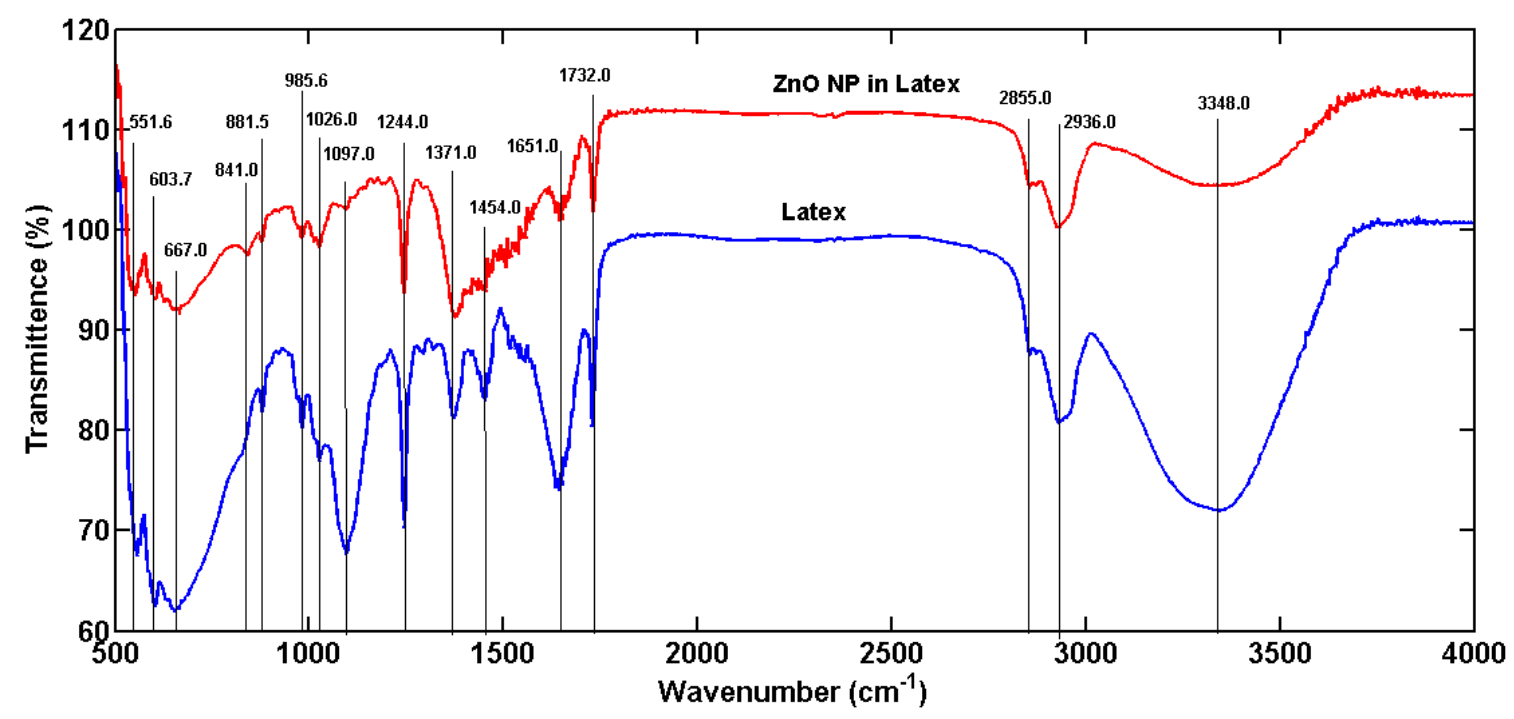

Figure 5. Fourier Transform Infrared (FTIR) spectra recoded from $\mathrm{KBr}$ pellets containing dry powder samples of ZnONP-GS in latex (red) and milky latex (blue) from C. gigantea.

\subsection{ROS Generation, Cell Death, and Lipid Peroxidation}

At the outset, in a pilot experiment, it was necessary to rule out that the latex at $1 \%$ concentration induced any significant effect on the biochemical or biological endpoints measured in the present study. After establishing the fact that the latex at the aforesaid concentration, comparable to distilled water, was non-toxic, in all the subsequent experiments only distilled water was used to serve as the negative control.

The cytochemical visualization and spectrophotometric analysis revealed that $\mathrm{Zn}^{2+}, \mathrm{ZnoNP}-\mathrm{S}$, and ZnONP-GS enhanced the generation of ROS: $\mathrm{O}_{2}{ }^{\bullet-}, \mathrm{H}_{2} \mathrm{O}_{2}$, and $\bullet{ }^{\bullet} \mathrm{OH}$ (Figure 6) were associated with the concomitant induction of cell death and lipid peroxidation in a dose-dependent fashion (Figure 7). Among the three agonists tested, $\mathrm{Zn}^{2+}$ was found to be the most effective to induce significantly the formation of ROS ( $p \leq 0.01)$, as revealed from the dose-dependent increase in the generation of $\mathrm{O}_{2}{ }^{\bullet-}\left(\mathrm{R}^{2}=0.81\right), \mathrm{H}_{2} \mathrm{O}_{2}\left(\mathrm{R}^{2}=0.97\right)$, or ${ }^{\bullet} \mathrm{OH}\left(\mathrm{R}^{2}=0.96\right)$, followed by the ZnONP-S $\left(\mathrm{R}^{2}=0.83,0.97\right.$, 
$0.96)$ and ZnONP-GS $\left(R^{2}=0.81,0.99,0.93\right)$. Although the induction of cell death was observed at concentrations 10 and $20 \mathrm{mg} \cdot \mathrm{L}^{-1}$, the difference was evident at concentrations $\geq 40 \mathrm{mg} \cdot \mathrm{L}^{-1}$. For lipid peroxidation, this difference was strikingly evident from the dose of $10 \mathrm{mg} \cdot \mathrm{L}^{-1}$ onwards, underscoring $\mathrm{Zn}^{2+}$ as more effective than both ZnONP-S and ZnOMP-GS in inducing ROS generation, cell death, and lipid peroxidation.
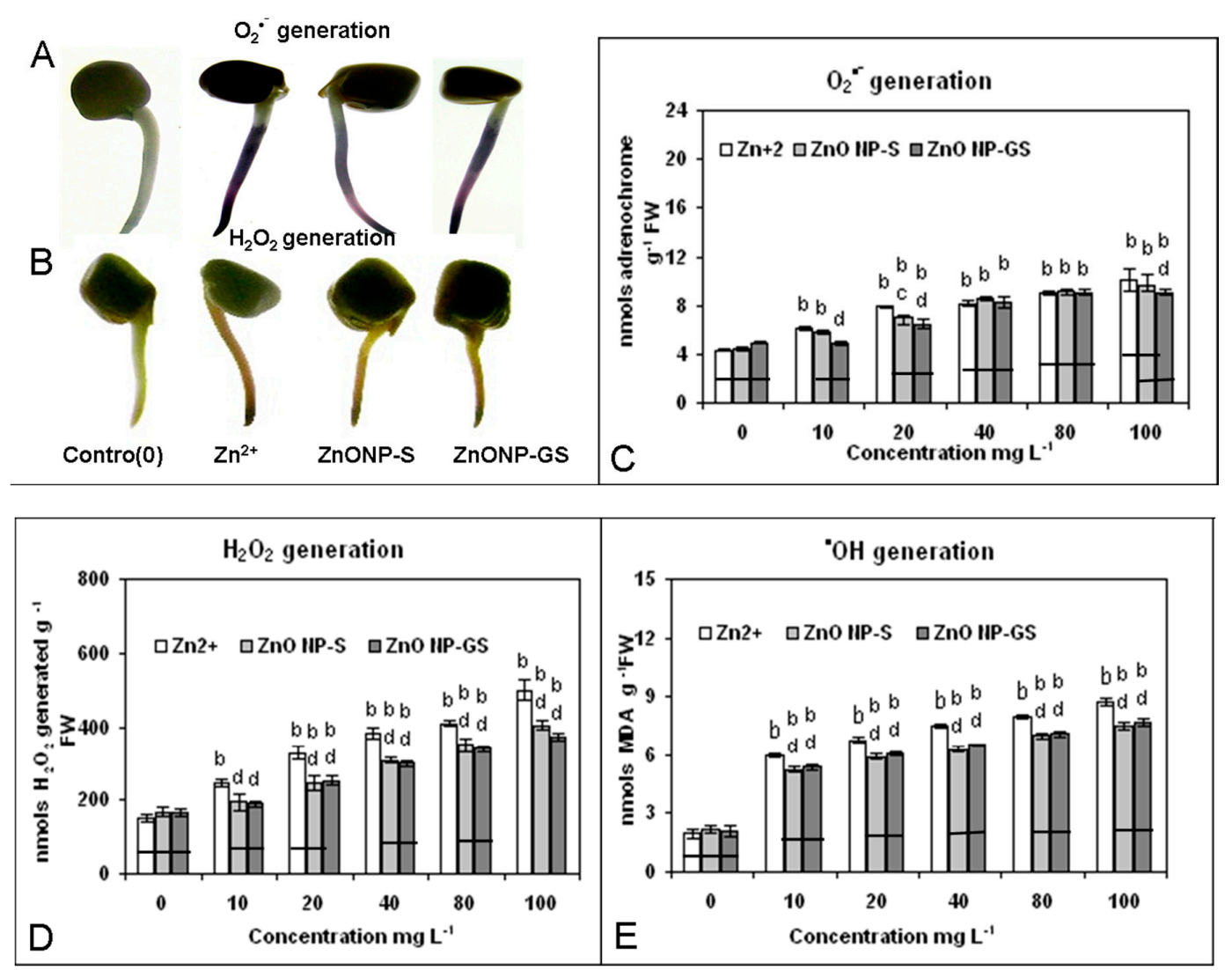

Figure 6. Cytochemical visualization of $(\mathbf{A}) \mathrm{O}_{2}{ }^{\bullet-}$, (B) $\mathrm{H}_{2} \mathrm{O}_{2}$ in roots of germinating seeds treated with $\mathrm{Zn}^{2+}$ or AnONPs at a single concentration $\left(0 \mathrm{or} 80 \mathrm{mg} \cdot \mathrm{L}^{-1}\right)$; spectrophotometric determination of (C) $\mathrm{O}_{2}{ }^{\bullet-}$, (D) $\mathrm{H}_{2} \mathrm{O}_{2}$, and (E) ${ }^{\bullet} \mathrm{OH}$ in roots of germinating seeds of $C$. gigantea treated with $\mathrm{Zn}^{2+}$ or $\mathrm{ZnONPs}$ at different concentrations $\left(0-100 \mathrm{mg} \cdot \mathrm{L}^{-1}\right)$. Increase significant at $p \leq 0.01(\mathrm{~b})$ compared to the control (0), and decrease significant at $p \leq 0.05$ (c) or 0.01 (d) compared to $\mathrm{Zn}^{2+}$. The horizontal bar denotes no significant difference between the treatments at $p \leq 0.05,(n=6)$.

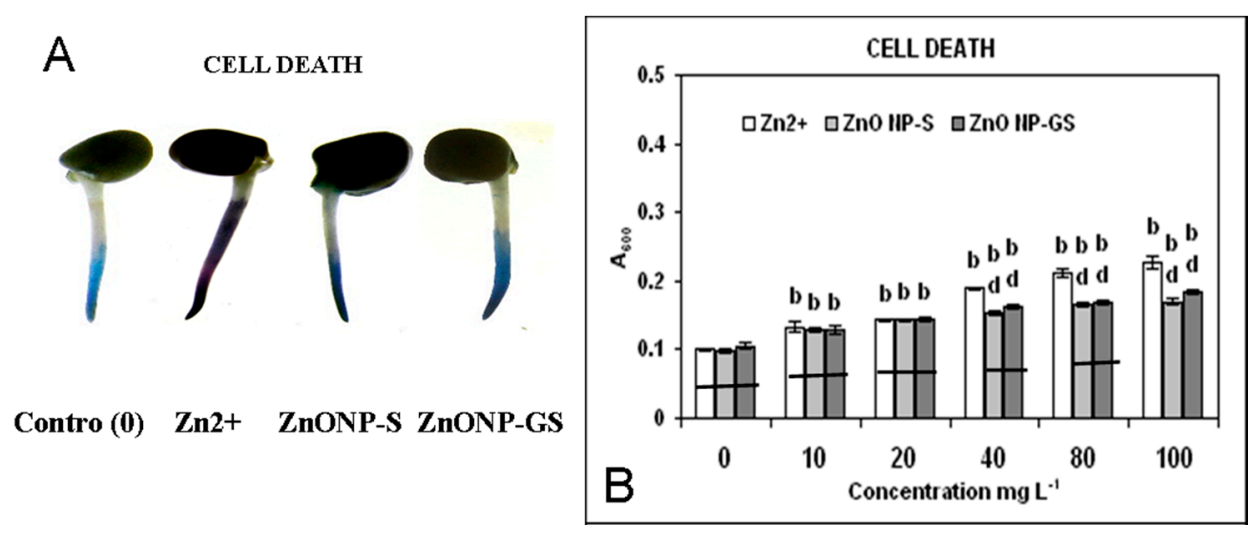

Figure 7. Cont. 


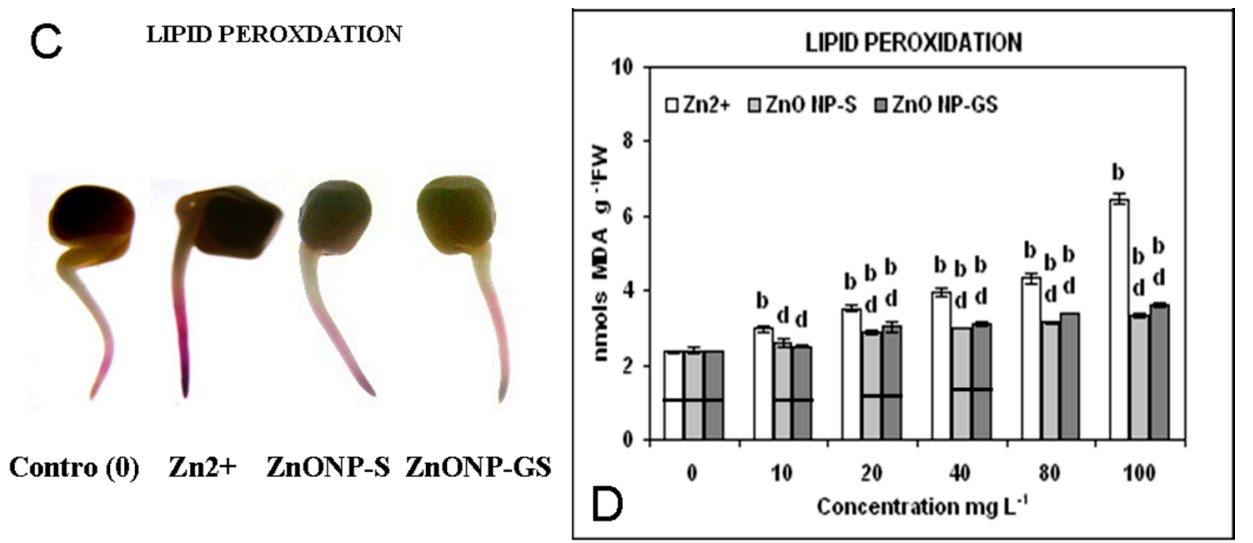

Figure 7. Cytochemical visualization of $(\mathbf{A})$ cell death and $(\mathbf{C})$ lipid peroxidation in roots of germinating seeds treated with $\mathrm{Zn}^{2+}$ and $\mathrm{ZnONPs}$ at a single concentration $\left(0\right.$ or $\left.80 \mathrm{mg} \cdot \mathrm{L}^{-1}\right)$; Spectrophotmetric determination of (B) cell death and (D) in roots of germinating seeds of $C$. gigantea treated with $\mathrm{Zn}^{2+}$ or $\mathrm{ZnONPs}$ at different concentrations $\left(0-100 \mathrm{mg} \cdot \mathrm{L}^{-1}\right)$. Increase significant at $p \leq 0.01(\mathrm{~b})$ compared to the control (0), and decrease significant at $p \leq 0.01$ (d) compared to $\mathrm{Zn}^{2+}$. The horizontal bar denotes no significant difference between the treatments at $p \leq 0.05,(n=6)$.

\subsection{Activity of Antioxidant Enzymes}

The antioxidative enzymes responded differently to $\mathrm{Zn}^{2+}$, ZnONP-S, and ZnONP-GS (Figure 8). Catalase activity was significantly $(p \leq 0.01)$ inhibited by $\mathrm{Zn}^{2+}\left(\mathrm{R}^{2}=0.96\right)$, ZnONP-S $\left(\mathrm{R}^{2}=0.99\right)$, and ZnONP-GS $\left(\mathrm{R}^{2}=0.97\right)$ showing a dose-response trend. In contrast, $\mathrm{Zn}^{2+}, \mathrm{ZnONP-S}$, and $\mathrm{ZnONP-GS}$ significantly induced $(p \leq 0.01)$ the activities of $\operatorname{SOD}\left(R^{2}=0.96,97,96\right), \operatorname{GPX}\left(R^{2}=0.77,97,98\right)$, and APX $\left(R^{2}=0.95,98,99\right)$ in a dose-dependent manner. Once again, $\mathrm{Zn}^{2+}$ appeared to be more effective than both the ZnONP-S and ZnOMP-GS in altering the activities of antioxidant enzymes.

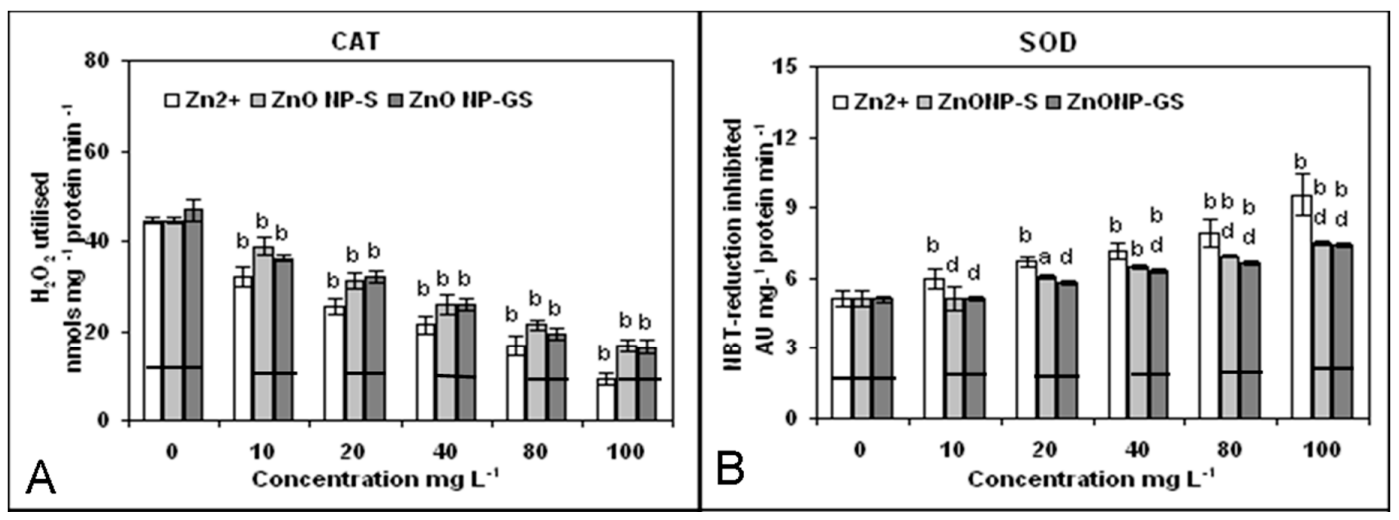

Figure 8. Cont. 


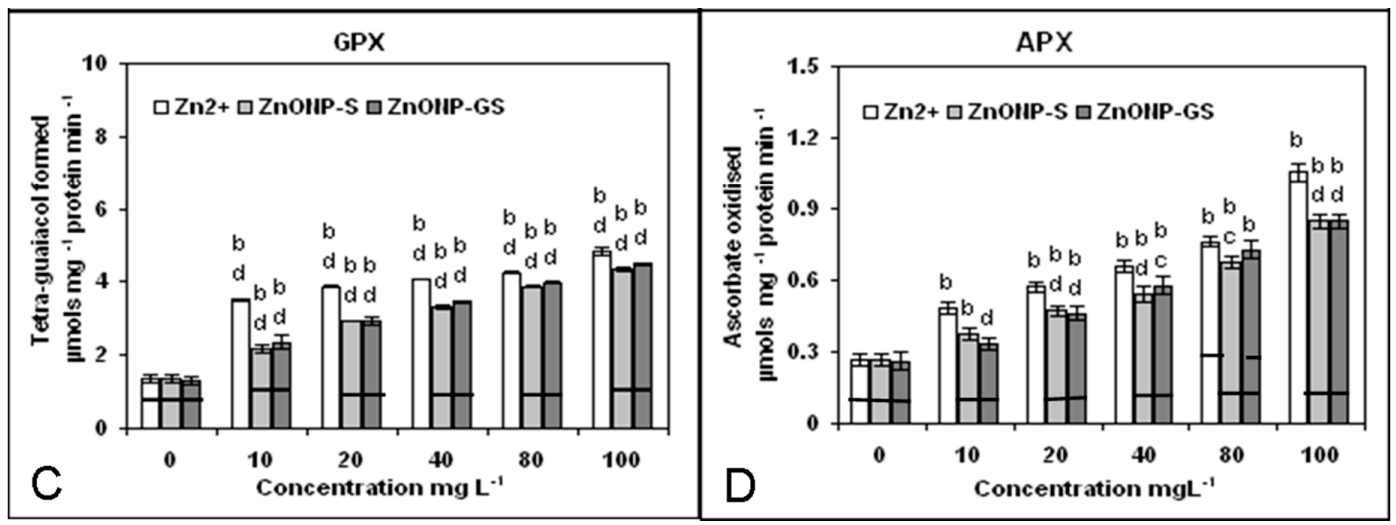

Figure 8. Activity of antioxidant enzymes (A) catalase (CAT), (B) superoxide dismutase (SOD), (C) guaiacol peroxidase (GPX), and (D) ascorpbate peroxidase (APX) in the root tissue of germinating seeds of $C$. gigantea treated with $\mathrm{Zn}^{2+}$ or $\mathrm{ZnONPs}$ at different concentrations $\left(0-100 \mathrm{mg} \cdot \mathrm{L}^{-1}\right)$. Increase significant at $p \leq 0.05$ (a) or 0.01 (b) compared to the control (0), and decrease significant at $p \leq 0.05$ (c) or $0.01(\mathrm{~d})$ compared to $\mathrm{Zn}^{2+}$. The horizontal bar denotes no significant difference between the treatments at $p \leq 0.05,(n=6)$.

\subsection{Assessment of DNA Damage}

The Comet assay that determines the DNA damage based on Tail DNA (\%) revealed that $\mathrm{Zn}^{2+}$ $\left(R^{2}=0.98\right)$, ZnONP-S $\left(R^{2}=0.96\right)$, and ZnONP-GS $\left(R^{2}=0.93\right)$ significantly induced DNA damage $(p \leq 0.01)$ in a dose-dependent manner (Figure 9). However, $\mathrm{Zn}^{2+}$ at the dose of $100 \mathrm{mg} \cdot \mathrm{L}^{-1}$ was toxic, as revealed by the comets showing nuclear disintegration or necrosis.

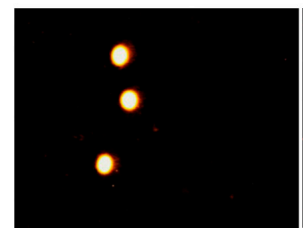

A Control (0)

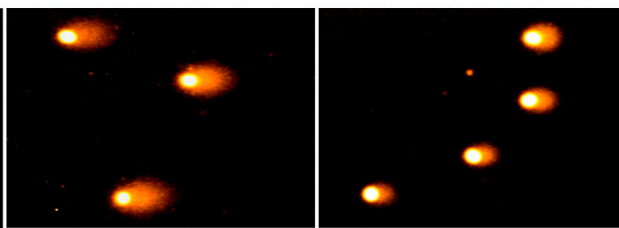

ZnONP-S

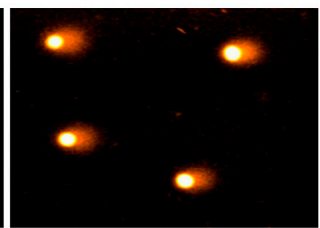

ZnONP-GS

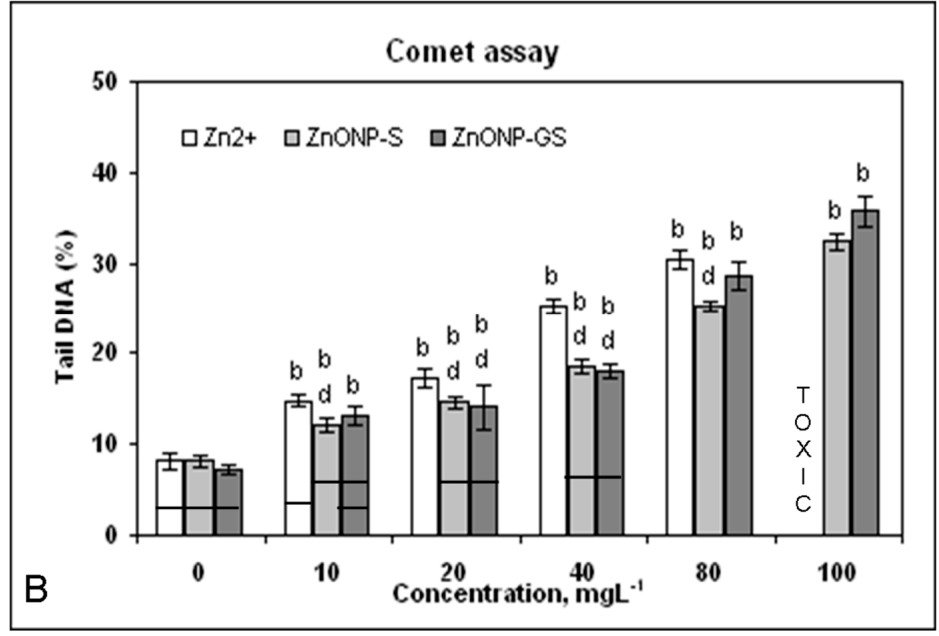

Figure 9. (A) DNA damage visualized in form of Comets in root cells from germinating seeds of C. gigantea treated with $\mathrm{Zn}^{2+}$ or $\mathrm{ZnONPs}$ at a single concentration, 0 or $40 \mathrm{mg} \cdot \mathrm{L}^{-1}$; (B) Dose-dependent induction of DNA damage by $\mathrm{Zn}^{2+}$ or $\mathrm{ZnONPs}$ at a range of concentrations $\left(0-100 \mathrm{mg} \cdot \mathrm{L}^{-1}\right)$. Increase significant at $p \leq 0.01$ (b) compared to the control (0), and decrease significant at $p \leq 0.01$ (d) compared to $\mathrm{Zn}^{2+}$. The horizontal bar denotes no significant difference between the treatments at $p \leq 0.05,(n=6)$. 


\subsection{Effect of Tiron and DMTU on ZnONP-Induced ROS Generation, Cell Death, and DNA Damage}

The ROS scavengers, Tiron and DMTU $(10$ and $20 \mu \mathrm{M})$, did not appear to alter the generation of $\mathrm{O}_{2}{ }^{\bullet-}$ and $\mathrm{H}_{2} \mathrm{O}_{2}$ (Figure 10). However, the priming of the roots with Tiron and DMTU $(10 \mu \mathrm{M})$ had little or no effect on the ROS generation, but the priming of the roots with both scavengers at the dose of $20 \mu \mathrm{M}$ significantly attenuated the generation of $\mathrm{O}_{2}{ }^{\bullet-}$ and $\mathrm{H}_{2} \mathrm{O}_{2}$, cell death, and DNA damage that was induced by both the ZnONPs at the dose of $80 \mathrm{mg} \cdot \mathrm{L}^{-1}(p \leq 0.01)$.

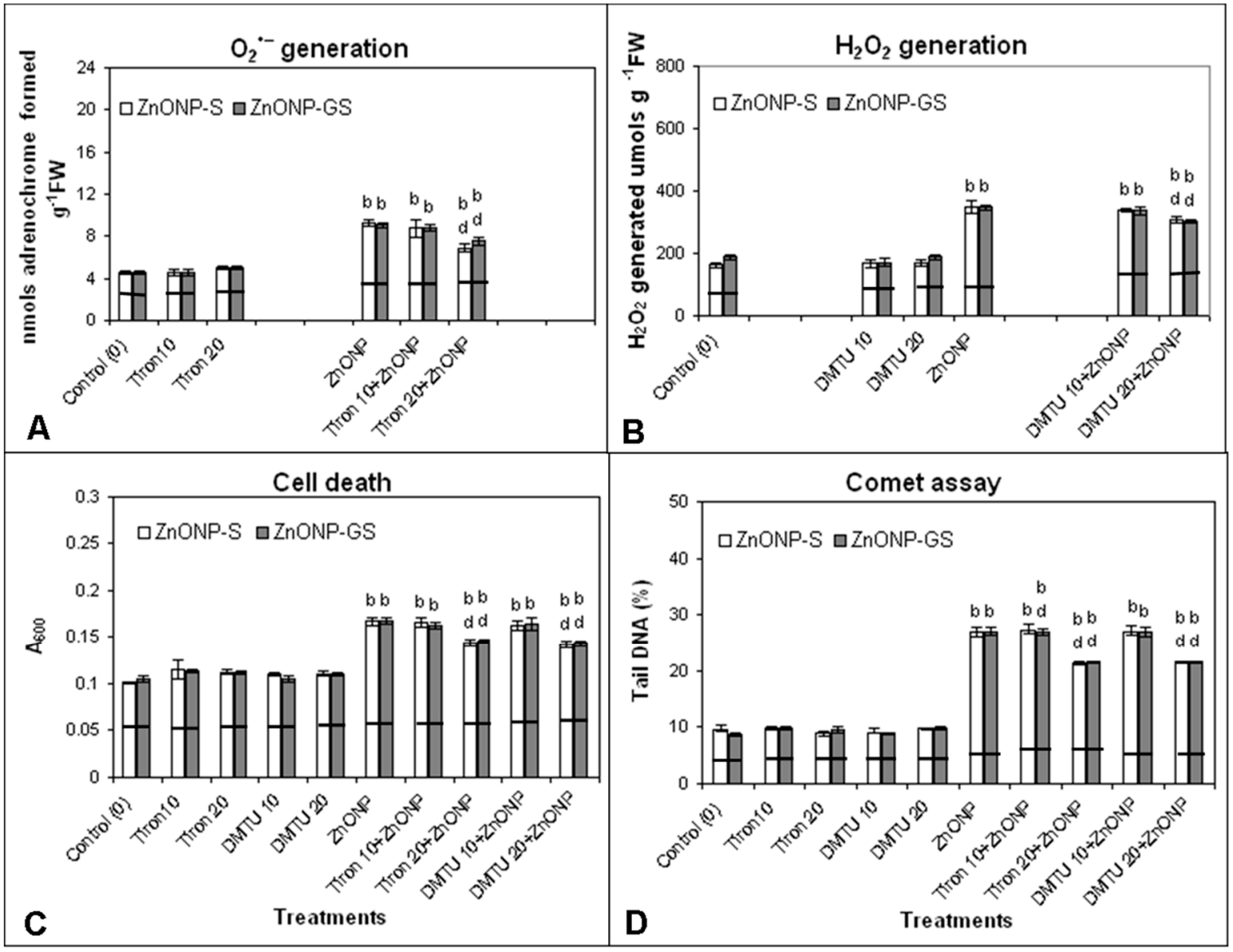

Figure 10. Effect of Tiron- or DMTU-priming at concentrations of 10 and $20 \mu \mathrm{M}$ on the induction of (A) $\mathrm{O}_{2} \bullet-$ generation, (B) $\mathrm{H}_{2} \mathrm{O}_{2}$ generation, (C) cell death, and (D) DNA damage in roots of germinating seeds of $C$. gigantea treated with ZnONP-GS at $80 \mathrm{mg} \cdot \mathrm{L}^{-1}$. Increase significant at $p \leq 0.01$ (b) compared to the control (0), and decrease significant at $p \leq 0.01$ (d) compared to ZnONP-GS. The horizontal bar denotes no significant difference between the treatments at $p \leq 0.05,(n=6)$.

\section{Discussion}

\subsection{Green Synthesis and Characterization of ZnONP-GS}

The UV-visible spectrophotometry employed in the present study was a preparatory analysis to monitor the synthesis of $\mathrm{ZnONP}$ in the crude reaction mixture. The signal $\left(\lambda_{\max }\right)$ observed at $281 \mathrm{~nm}$, therefore, might have been contributed by other soluble impurities or other side products formed along with the synthesis of ZnONP (Figure 1). The $\lambda_{\max }$ observed separately for the pure ZnONP-GS synthesized in the present study was at $306 \mathrm{~nm}$, which suggested a blue shift in absorption as compared with the bulk of the $\mathrm{ZnO}(360 \mathrm{~nm})$ and was attributed to the quantum confinement property of NPs, indicating a decrease in the particle size [11,13]. It may be clarified that UV absorption by NPs does not refer to atomic or molecular vibration, but this type of absorption is through a cooperative phenomenon 
called surface plasmon resonance or SPR. This SPR absorption, therefore, depends on the surface curvature and particle size [11]. The TEM analysis in the present study indicated that the ZnONP-GS sample had a range of shapes from spherical to hexagonal (Figure 3).

The first step in this process involves breaking down $\mathrm{Zn}\left(\mathrm{CH}_{3} \mathrm{COO}\right)_{2}$ to form $\mathrm{Zn}(\mathrm{OH})_{2}$ by the action of $\mathrm{NaOH}$. At a pH of $12, \mathrm{Zn}(\mathrm{OH})_{2}$ is the prominent species in solution, which then generates $\mathrm{ZnO}$ nuclei followed by $\mathrm{ZnO}$ crystal growth [11,12]. The intensity of peaks in XRD profiles indicated the Wurtzite crystalline nature of the ZnONP-GS, as with the ZnONP-S; the XRD peak positions corresponded to those reported in the JCPDS 361451 page (Figure 4). The 100\% intense peaks were subjected to Scherrer analysis, and the particle sizes were found to be $25.1 \mathrm{~nm}$ and $48.6 \mathrm{~nm}$ in the ZnONP-GS and ZnONP-S samples, respectively. The FTIR spectrum of the latex of $C$. gigantea without or with the ZnONP-GS (Figure 5) revealed absorption peaks at $3348 \mathrm{~cm}^{-1}$ due to OH stretching vibration and at $2855,2936 \mathrm{~cm}^{-1}$ due to $-\mathrm{CH}_{2}-$ stretching vibration. The characteristic peaks at $1732 \mathrm{~cm}^{-1}$ (C=O stretching), $1651 \mathrm{~cm}^{-1}$ ( $\mathrm{N}-\mathrm{H}$ bending), $1454 \mathrm{~cm}^{-1}$ (C-H bending), $1371 \mathrm{~cm}^{-1}$ (C-H rocking), and $1244 \mathrm{~cm}^{-1}$ (ester carbonyl) and the peaks at $1097 \mathrm{~cm}^{-1}, 1026 \mathrm{~cm}^{-1}$, and $985.6 \mathrm{~cm}^{-1}$ (C-N of primary amines) clearly indicate the presence of lupeol, calotropin, calotoxin, and uscharidin, the latex proteins [34-36]. The above spectral features associated with the ZnONP-GS in latex seem to be as a result of the binding of latex molecules or proteins to the surface of ZnONPs, serving as capping and stabilizing agents [37]. The addition of latex at such a low concentration as $1 \%$ did not introduce any impurity to the ZnONP, as revealed by the XRD analysis reported here. The faint shadow-like contrast around the NPs in TEM rather confirms the capping action of the latex. Ha et al. [11] have reported the synthesis of the $\mathrm{ZnONPs}$ from precursors, $\mathrm{Zn}\left(\mathrm{CH}_{3} \mathrm{COO}\right)_{2}$ and $\mathrm{NaOH}$, by using a conventional heating process or with the aid of microwave irradiation. Furthermore, they have been able to alter the shape by capping the ZnONPs by using surfactants like sodiumdodecyl sulphate (SDS), hexadecylcetyltrimethyl ammonium bromide (CTAB), or polyvinyl pyrrolidone (PVP). The results depicted in Figure 1 led to the conclusion that the latex plays two important roles in the whole process. Firstly, it acts as a capping agent even at the lowest concentration studied here. And secondly, the reduction of $\mathrm{Zn}\left(\mathrm{CH}_{3} \mathrm{COO}\right)_{2}$ by $\mathrm{NaOH}$ is effectively catalyzed by the latex at higher concentrations. Since the latex effectively accomplishes the capping action, the particle size of the ZnONP remains limited to $25 \mathrm{~nm}$ in all the cases, as indicated by the SPR luminescence peak appearing at the same wave length of $281 \mathrm{~nm}$. Osman and Mustafa [12] have reported the synthesis of the ZnONP, applying a hydrothermal technique using 0.05 or $0.1 \mathrm{M} \mathrm{Zn}\left(\mathrm{CH}_{3} \mathrm{COO}\right)_{2}: \mathrm{NaOH}$ at 1:1 ratio. They have reported that, depending on the concentration of 0.05 or $0.1 \mathrm{M}$, the average NP size is found to be 75 or $54 \mathrm{~nm}$ in diameter, respectively [12]. On the contrary, in our present study, we used an extremely low concentration of the reducing agent $(\mathrm{NaOH})$ so that the reduction reaction could be precisely controlled and the NPs could be effectively capped by the latex, limiting growth not beyond $25 \mathrm{~nm}$.

\subsection{ZnONPs Induce Oxidative Stress}

Zinc is an essential micronutrient for plants, but, when in excess, $\mathrm{Zn}^{2+}$ causes oxidative stress in plants [38] even though the element is not redox-active. The ZnONPs are shown to be phytotoxic, as screened by the Arabidopsis thaliana [39], Trticum aestivum [7], and Brassica nigra [40] seedling assays. Similar to its antibacterial action, the phytotoxicity of ZnONPs is also attributed to the ROS generation, release of $\mathrm{Zn}^{2+}$, cellular membrane dysfunction, and NP internalization [41]. An oxidative stress signature, comprising multiple oxidative stress-related cellular, molecular, and metabolic events, is characteristic of the disturbance of redox homeostasis and signaling.

In the present study, $\mathrm{Zn}\left(\mathrm{CH}_{3} \mathrm{COO}\right)_{2}$ solutions at different concentrations were included as the positive control, where $\mathrm{Zn}^{2+}$ ions served as the source for $\mathrm{Zn}$-toxicity to the root system. In the current study, the ZnONP-GS synthesized via the green route was thoroughly and repeatedly washed to ensure that it was free from any residual $\mathrm{Zn}^{2+}$ ions. This was confirmed by measuring the conductivity (a measure of $\mathrm{Zn}^{2+}$ ) of the supernatant of the experimental solutions of the ZnONP-GS at different concentrations $\left(0-100 \mathrm{mg} \cdot \mathrm{L}^{-1}\right)$. In a control experiment, the conductivity was measured in pure 
$\mathrm{Zn}\left(\mathrm{CH}_{3} \mathrm{COO}\right)_{2}$ solutions at different concentrations, wherein the conductivity appeared to increase with the increase in concentration of $\mathrm{Zn}\left(\mathrm{CH}_{3} \mathrm{COO}\right)_{2}$. This confirms that the presence of $\mathrm{Zn}^{2+}$ ions in solution can be detected by conductivity measurements. Our conductivity measurements of the supernatant solutions over the ZnONP-GS showed no increase in conductivity over pure solvent (distilled water), indicating the absence of free $\mathrm{Zn}^{2+}$ ions that would contribute to the toxicity. The results suggested that $\mathrm{Zn}^{2+}$, and to a lesser extent the ZnONPs, enhanced the generation of $\operatorname{ROS}\left(\mathrm{O}_{2}{ }^{\bullet-}, \mathrm{H}_{2} \mathrm{O}_{2}\right.$ and $\left.{ }^{\bullet} \mathrm{OH}\right)$ (Figure 6), which is indicative of the membrane damage marked by the cell death and lipid peroxidation in the roots of germinating L. sativus seeds (Figure 7). The oxidative stress was further corroborated by the observed dose-dependent decrease of activity of CAT and the increase in the activities of SOD, GPX, and APX, induced by $\mathrm{Zn}^{2+}$ and the $\mathrm{ZnONPs}$ (Figure 8). The changed activities of these antioxidant enzymes serve as the markers of oxidative stress [42]. The $\mathrm{Zn}^{2+}$-induced decline in CAT activity with concomitant increases in the activities of SOD, GPX, and APX have been reported in studies on duckweed [43] and maize [44]. Among the antioxidant enzymes, the first enzyme is CAT, which catalyzes the dismutation of two molecules of $\mathrm{H}_{2} \mathrm{O}_{2}$ into water and oxygen, is very sensitive to $\mathrm{O}_{2}{ }^{\bullet-}$, and is inactivated by the elevated levels of $\mathrm{O}_{2}{ }^{\bullet-}$ [45]. The second enzyme, SOD, catalyzes the dismutation of $\mathrm{O}_{2}{ }^{--}$to $\mathrm{O}_{2}$ and $\mathrm{H}_{2} \mathrm{O}_{2}$. The third enzyme GPX, an effective quencher of ROS and peroxy redicals under stress conditions, showing a correlation with sub-lethal doses of metals, is considered a marker of metal toxicity [42]. The last enzyme investigated in the present study, APX, is regarded as one of the most widely distributed antioxidant enzymes in the plant cells and has greater affinity for $\mathrm{H}_{2} \mathrm{O}_{2}$ than CAT, thus making APX as an efficient scavenger of $\mathrm{H}_{2} \mathrm{O}_{2}$ under stress [42]. As compared to the $\mathrm{ZnONPs}, \mathrm{Zn}^{2+}$ was more effective at altering the activities of the antioxidant enzymes in the present study. Thus, the results of the present study underscored the importance of the ZnONPs-induced ROS generation and oxidative stress as valid biomarkers of the ZnONP-mediated phytotoxicity assay.

\subsection{ROS Scavengers Alleviate ZnONP-Induced DNA Damage}

From the standpoint of environmental health, Remedios et al. emphasize the need for more information on the genotoxicity of metal NPs, which is reported by the plant bioassays as well as the animal and human cell lines [46]. The ZnONPs have been reported to induce cytotoxicity, genotoxicity, and/or DNA damage in the root meristem cells of Allium cepa [47]; DNA damage in the epidermal cell line (A431) [48] and human neuroblastoma SHSY5Y cell line [49]; and somatic mutation and DNA damage in Drosophila melanogaster [50]. Also, $\mathrm{Zn}^{2+}$ has been shown to cause significant DNA damage in Nicotiana tabacum in the root but not leaf cells, attributed to efficient $\mathrm{H}_{2} \mathrm{O}_{2}$ scavenging by the enhanced antioxidative enzymes activity in leaf cells [51]. From the results of the majority of earlier reported studies, genotoxicity and DNA damage have been attributed to the oxidative stress induced by $\mathrm{Zn}^{2+}$ or ZnONPs. In the present study, it was clearly evident that $\mathrm{Zn}^{2+}$ and the $\mathrm{ZnONP}$ significantly induced DNA damage, wherein the former was more effective than the latter (Figure 9). The ROS scavengers, Tiron and DMTU, were used to establish the role of ROS i ZnONP-induced DNA damage and cell death. The concentrations of ROS scavengers were kept low to avoid their toxic actions. The ROS scavengers at such low concentrations were not expected to completely block the DNA damage or cell death but to alleviate toxicity of the ZnONPs. However, the priming of the roots with Tiron and DTMU $(20 \mu \mathrm{M})$ significantly alleviated the cell death and DNA damage induced by the $\mathrm{ZnONP}$ alone (Figure 10), suggesting an underlying role for ROS in ZnONP-induced cell death and DNA.

\section{Conclusions}

From the results of the present study, it was concluded that the ZnONP-GS synthesized from $\mathrm{Zn}\left(\mathrm{CH}_{3} \mathrm{COO}\right)_{2}$ by the alkaline precipitation method using the milky latex of $\mathrm{C}$. gigantea induced oxidative stress in the root assay system of $L$. sativus, which was comparable to that induced by the 
commercially available $\mathrm{ZnONP-S}$ but to a lesser extent than that induced by $\mathrm{Zn}^{2+}$ alone. The findings underscore the role of ROS in ZnONP-induced DNA damage.

Acknowledgments: This work was supported by the University Grants Commission, New Delhi through the award of a Post-Doctoral Fellowship (No. F.15-25/12/SA-II) to Kamal K. Panda, an Emeritus Fellowship (No. F.6-6/2013-14/EMERITUS-2013-14-GEN-2681/SA-II) to Brahma B. Panda, and a Rajiv Gandhi National Fellowship to Dambaru Golari and A. Venugopal The authors acknowledge the Berhampur University for support and facilities to conduct the present research. The technical assistance provided by Gajendra Saini and Manoj P. Singh with the TEM and EDX at the Advanced Instrumentation Research Facilities, JNU, New Delhi is gratefully acknowledged. The authors appreciate the assistance rendered by S. Kalavathi of the Material Science Division, IGCAR, Kalpakum with XRD.

Author Contributions: Kamal K. Panda and Brahma B. Panda conceived, designed, and performed the experiments; V. Mohan M. Achary assisted with the EDX and TEM analyses, whereas Dambaru Golari helped with spectrophotometry and A. Venugopal with Comet assay. Ganngam Phaomie did FTIR analysis. Hrushi K. Sahu helped with XRD analysis. Brahma B. Panda supervised the study and wrote and reviewed the manuscript with inputs by Kamal K. Panda, Narasimham L. Parinandi, and Hrushi K. Sahu. All authors have read and approved the final manuscript.

Conflicts of Interest: The authors declare no conflict of interest.

\section{References}

1. Nowack, B.; Bucheli, T.D. Occurrence, behavior and effects of nanoparticles in the environment. Environ. Pollut. 2007, 150, 5-22. [CrossRef] [PubMed]

2. Handy, R.; Kamme, V.D.F.; Lead, J.R.; Hasselov, M.; Owen, R.; Crane, M. The ecotoxicology and chemistry of manufactured nanoparticles. Ecotoxicology 2008, 17, 287-314. [CrossRef] [PubMed]

3. Lowry, G.V.; Hotze, E.M.; Bernhardt, E.S.; Dionysiou, D.D.; Wiesner, M.R.; Xing, B. Environmental occurrences, behavior, fate, and ecological effects of nanomaterials: An introduction to the special series. J. Environ. Qual. 2010, 39, 1867-1874. [CrossRef] [PubMed]

4. Vaseem, M.; Umar, A.; Hanh, Y.-B. ZnO nanoparticles: Growth, properties, and applications. In Metal Oxide Nanostructures and Their Applications; Ummer, A., Hanh, Y.-B., Eds.; American Scientific Publishers: Los Angeles, CA, USA, 2010; Volume 5, pp. 1-36.

5. Xie, Y.; He, Y.; Irwin, P.L.; Jin, T.; Shi, X. Antibacterial activity and mechanism of action of zinc oxide nanoparticles against Campylobacter jejuni. Appl. Environ. Microbiol. 2001, 77, 2325-2331. [CrossRef] [PubMed]

6. Rasmussen, J.W.; Martinez, E.; Louka, P.; Denise, G.; Wingett, D.G. Zinc oxide nanoparticles for selective destruction of tumor cells and potential for drug delivery applications. Expert Opin. Drug Deliv. 2010, 7 , 1063-1077. [CrossRef] [PubMed]

7. Watson, J.-L.; Fang, T.; Dimkpa, C.O.; Britt, D.W.; McLean, J.E.; Jacobson, A.; Anderson, A.J. The phytotoxicity of $\mathrm{ZnO}$ nanoparticles on wheat varies with soil properties. Biometals 2015, 28, 101-112. [CrossRef] [PubMed]

8. Ma, H.; Williams, P.L.; Diamond, S.A. Ecotoxicity of manufactured ZnO nanoparticles-A review. Environ. Pollut. 2013, 172, 76-85. [CrossRef] [PubMed]

9. Brintha, S.R.; Ajitha, M. Synthesis and characterization of $\mathrm{ZnO}$ nanoparticles via aqueous solution, sol-gel and hydrothermal methods. IOSR J. Appl. Chem. 2015, 8, 66-72.

10. Mishra, S.K.; Srivastava, R.K.; Prakash, S.G. ZnO nanoparticles: Structural, optical and photoconductivity characteristics. J. Alloys Comp. 2012, 539, 1-6. [CrossRef]

11. Ha, T.T.; Canh, T.D.; Tuyen, N.V. A quick process for synthesis of ZnO Nanoparticles with the aid of microwave irradiation. ISRN Nanotechnol. 2013, 2013. [CrossRef]

12. Osman, D.A.M.; Mustafa, M.A. Synthesis and characterization of zinc oxide nanoparticles using zinc acetate dihydrate and sodium hydroxide. J. Nanosci. Nanoeng. 2015, 1, 248-251.

13. Moharram, A.H.; Mansour, S.A.; Hussein, M.A.; Rashad, M. Direct precipitation and characterization of ZnO nanoparticles. J. Nanomater. 2014, 2014. [CrossRef]

14. Jha, A.K.; Prasad, K.; Kulkarni, A.R. Plant system: Nature's nanofactory. Colloids Surf. B Biointerfaces 2009, 73, 219-223. [CrossRef] [PubMed]

15. Pantidos, N.; Horsfall, L.E. Biological synthesis of metallic nanoparticles by bacteria, fungi and plants. J. Nanomed. Nanotechnol. 2014, 5, 5. [CrossRef] 
16. Mittal, A.K.; Chisti, Y.; Banerjee, U.C. Synthesis of metallic nanoparticles using plant extracts. Biotechnol. Adv. 2013, 31, 346-356. [CrossRef] [PubMed]

17. Sangeetha, G.; Rajeshwari, S.; Venckatesh, R. Green synthesis of zinc oxide nanoparticles by Aloe barbadensis miller leaf extract: Structure and optical properties. Mater. Res. Bull. 2011, 46, 2560-2566. [CrossRef]

18. Vidya, C.; Hiremath, S.; Chandraprabha, M.N.; Antonyraj, M.A.L.; Gopal, I.V.; Jain, A.; Bansal, K. Green synthesis of $\mathrm{ZnO}$ nanoparticles by Calotropis gigantea. Int. J. Curr. Eng. Technol. 2013, 1, 118-120. Available online: http://inpressco.com/category/ijcet (accessed on 24 February 2017).

19. Sabir, S.; Arshad, M.; Chaudhari, S.K. Zinc oxide nanoparticles for revolutionizing agriculture: Synthesis and applications. Sci. World J. 2014, 2014. [CrossRef] [PubMed]

20. Bhumi, G.; Savithriamma, N. Biological synthesis of zinc oxide nanoparticles from Catharanthus roseus (L.) G. Don. Leaf extract and validation for antibacterial activity. Int. J. Drug Dev. Res. 2004, 6, 208-214.

21. Yedurkar, S.; Maurya, C.; Mahanwar, P. Biosynthesis of zinc oxide manoparticles using Ixora coccinea leaf extract-A green approach. Open J. Synth. Theory Appl. 2016, 5, 1-14. [CrossRef]

22. Nagarajan, S.; Kuppusamy, K.A. Extracellular synthesis of zinc oxide nanoparticle using seaweeds of gulf of Mannar, India. J. Nanobiotechnol. 2013, 11, 39. [CrossRef] [PubMed]

23. Panda, K.K.; Achary, V.M.M.; Phaomie, G.; Sahu, H.K.; Parinandi, N.L.; Panda, B.B. Polyvinyl polypyrrolidone attenuates genotoxicity of silver nanoparticles synthesized via green route, tested in Lathyrus sativus L. root bioassay. Mutat. Res. 2016, 806, 11-23. [CrossRef] [PubMed]

24. Yamamoto, Y.; Kobayashi, Y.; Matsumoto, H. Lipid peroxidation is an early symptom triggered by aluminum, but not the primary cause of elongation inhibition in pea roots. Plant Physiol. 2001, 125, 199-208. [CrossRef] [PubMed]

25. Loreto, F.; Velikova, V. Isoprene produced by leaves protects the photosynthetic apparatus against ozone damage, quenches ozone products, and reduces lipid peroxidation of cellular membranes. Plant Physiol. 2001, 127, 1781-1787. [CrossRef] [PubMed]

26. Bradford, M.M. A rapid and sensitive method for quantification of microgram quantities of protein utilizing the principle of protein dye-binding. Anal. Biochem. 1976, 72, 248-254. [CrossRef]

27. Aebi, H. Catalase in vitro. Methods Enzymol. 1984, 105, 121-126. [PubMed]

28. Beauchamp, C.; Fridovich, I. Superoxide dismutase: Improved assays and an assay applicable to acrylamide gels. Anal. Biochem. 1971, 44, 276-287. [CrossRef]

29. Chance, B.; Maehly, A.C. Assay of catalase and peroxidases. Methods Enzymol. 1955, 2, 764-777. [CrossRef]

30. Chen, G.X.; Asada, K. Ascorbate peroxidase in tea leaves: Occurrence of two isozymes and the differences in their enzymatic and molecular properties. Plant Cell Physiol. 1989, 30, 987-998. [CrossRef]

31. Achary, V.M.M.; Patnaik, A.R.; Panda, B.B. Oxidative biomarkers in leaf tissue of barley seedlings in response to aluminum stress. Ecotoxicol. Environ. Saf. 2012, 75, 16-26. [CrossRef] [PubMed]

32. Pourrut, B.; Pinelli, E.; Mendiola, V.C.; Silvestre, J.; Douay, F. Recommendations for increasing alkaline comet assay reliability in plants. Mutagenesis 2015, 30,37-43. [CrossRef] [PubMed]

33. Daniel, W.W. Biostatistics-A Foundation for Analysis in the Health Sciences, 6th ed.; John Wiley: New York, NY, USA, 1995.

34. Saratha, V.; Pillai, S.I.; Subramanian, S. Isolation and characterization of lupeol, a triterpenoid from Calotropis gigantea latex. Int. J. Pharm. Sci. Rev. Res. 2011, 10, 54-57.

35. Kumar, P.S.; Suress, E.; Kalavathy, S. Review on a potential herb Calotropis gigantea (L.) R. Br. Sch. Acad. J. Pharm. 2013, 2, 135-143.

36. Rajkuberan, C.; Sudha, K.; Sathishkumar, G.; Sivaramakrishnan, S. Antibacterial and cytotoxic potential of silver nanoparticles synthesized using latex of Calotropis gigantea L. Spectrochim. Acta A Mol. Biomol. Spectrosc. 2015, 136, 924-930. [CrossRef] [PubMed]

37. Harne, S.; Sharma, A.; Dhaygude, M.; Joglekar, S.; Kodam, K.; Hudlikar, W. Novel route for rapid biosynthesis of copper nanoparticles using aqueous extract of Calotropis procera L. latex and their cytotoxicity on tumor cells. Colloids Surf. B Biointerfaces 2012, 95, 284-288. [CrossRef] [PubMed]

38. Remans, T.; Opdenakker, K.; Guisez, Y.; Carleer, R.; Schat, H.; Jaco Vangronsveld, J.; Cuypers, A. Exposure of Arabidopsis thaliana to excess $\mathrm{Zn}$ reveals a Zn-specific oxidative stress signature. Environ. Exp. Bot. 2012, 84, 61-71. [CrossRef] 
39. Lee, C.W.; Mahendra, S.; Zodrow, K.; Li, D.; Tsai, Y.-C.; Braam, J.; Alvarez, P.J.J. Developmental phytotoxicity of metal oxide nanoparticles to Arabidopsis thaliana. Environ. Toxicol. Chem. 2010, 29, 669-675. [CrossRef] [PubMed]

40. Zafar, H.; Ali, A.; Ali, J.S.; Haq, I.U.; Zia, M. Effect of ZnO Nanoparticles on Brassica nigra seedlings and stem explants: Growth dynamics and antioxidative response. Front. Plant Sci. 2016, 7, 535. [CrossRef] [PubMed]

41. Dutta, R.K.; Nenavathu, B.P.; Gangishetty, W.K.; Reddy, A.V.R. Studies on antibacterial activity of ZnO nanoparticles by ROS induced lipid peroxidation. Colloids Surf. B Biointerfaces 2012, 94, 143-150. [CrossRef] [PubMed]

42. Sharma, P.; Jha, A.B.; Dubey, R.S.; Pessarakli, M. Reactive oxygen species, oxidative damage, and antioxidative defense mechanism in plants under stressful conditions. J. Bot. 2012, 2012. [CrossRef]

43. Radic, S.; Babic, M.; Skobic, D.; Roje, V.; Pevalek-Kozlina, B. Ecotoxicological effects of aluminum and zinc on growth and antioxidants in Lemna minor L. Ecotoxicol. Environ. Saf. 2010, 73, 336-342. [CrossRef] [PubMed]

44. Cui, Y.; Zhao, N. Oxidative stress and change in plant metabolism of maize (Zea mays L.) growing in contaminated soil with elemental sulfur and toxic effect of zinc. Plant Soil Environ. 2011, 57, 34-39.

45. Fridovich, I. Biological effects of the superoxide radical. Arch. Biochem. Biophys. 1986, 247, 1-11. [CrossRef]

46. Remedios, C.; Rosario, F.; Bastos, V. Environmental nanoparticles interactions with plants: Morphological, physiological, and genotoxic aspects. J. Bot. 2012, 2012. [CrossRef]

47. Kumari, S.M.; Khan, S.; Pakrashi, S.; Mukherjee, A.; Chandrasekaran, N. Cytogenetic and genotoxic effects of zinc oxide nanoparticles on root cells of Allium cepa. J. Hazard. Mater. 2011, 190, 613-621. [CrossRef] [PubMed]

48. Sharma, V.; Shukla, R.K.; Saxena, N.; Parmar, D.; Das, M.; Dhawan, A. DNA damaging potential of zinc oxide nanoparticles in human epidermal cells. Toxicol. Lett. 2009, 185, 211-218. [CrossRef] [PubMed]

49. Valdiglesias, V.; Costa, C.; Kiliç, G.; Costa, S.; Pásaro, E.; Laffon, B.; Teixeira, J.P. Neuronal cytotoxicity and genotoxicity induced by zinc oxide nanoparticles. Environ. Int. 2013, 55, 92-100. [CrossRef] [PubMed]

50. Carmona, E.R.; Inostroza-Blancheteau, C.; Rubio, L.; Marcos, R. Genotoxic and oxidative stress potential of nanosized and bulk zinc oxide particles in Drosophila melanogaster. Toxicol. Ind. Health 2015, 1-5. [CrossRef] [PubMed]

51. Procházková, D.; Wilhelmová, N.; Pavlíková, D.; Száková, J.; Gichner, T. Zinc induces DNA damage in tobacco roots. Biol. Plant. 2013, 57, 783-787. [CrossRef] 